La represión antiperonista y su justificación en Jujuy en tiempos de la Revolución Libertadora

Fernando Aníbal Castillo

páginas / año 8 - n 16 / ISSN 1851-992X / pp. 82-98 / 2016

http://revistapaginas.unr.edu.ar/index.php/RevPaginas

\title{
La represión antiperonista y su justificación en Jujuy en tiempos de la Revolución Libertadora
}

\section{Antiperonist repression and its justification in Jujuy for the period of Revolución Libertadora}

\author{
Fernando Aníbal Castillo \\ Unidad de Investigación en Historia Regional (Universidad Nacional de Jujuy) \\ Investigaciones Socio-históricas Regionales \\ Consejo Nacional de Investigaciones Científicas y Técnicas - Argentina \\ ferredbo@yahoo.com.ar
}

\begin{abstract}
Resumen
La destitución del gobierno peronista, ejecutada en septiembre de 1955 mediante un golpe de Estado, conllevó la institución de una administración antiperonista, denominada "Revolución Libertadora", cuya lógica apuntaba a la proscripción absoluta del peronismo. Este régimen ejerció la represión contra el peronismo mediante diversos procedimientos. Estas medidas se pusieron en operación en todo el territorio nacional, y alcanzaron de esta forma a la provincia de Jujuy. En este distrito, la política estatal de coacción al peronismo comportó medidas como la encarcelación de sus militantes y la supresión de sus símbolos del espacio público. Este dispositivo se justificó en términos generales en esta jurisdicción mediante la apelación a los principios del antiperonismo radicalizado, basado en la representación del peronismo como un régimen totalitario.
\end{abstract}

Palabras claves

Antiperonismo, Jujuy, Representaciones, Represión política, Revolución Libertadora

\begin{abstract}
Peronist administration was overthrown in September 1955 by a coup d'état; as a result of such event, an Antiperonist government, so-called "Revolución Libertadora", was established. This regime introduced political repression against Peronism; thus, state logic aimed to banish Peronism in an absolutely way. In order to achieve that objective, several procedures were executed. This manoeuvres were carried out in the whole country, including Jujuy (a northern Argentina province). In this district, mechanisms such as the imprisonment of its militants and the suppression of its symbols from public space were deployed. In this jurisdiction, state policy pointed to repress Peronism was justified in a general way by the means of radicalized Antiperonism principles, specially the representation of Peronism as a totalitarian regime.
\end{abstract}

\section{Keywords}

Esta obra está sujeta a la Licencia Reconocimiento-NoComercial-CompartirIgual 4.0 Internacional de Creative Commons. http://creativecommons.org/licenses/by-nc-sa/4.0/ (cc) BY-NC-SA 


\section{Fernando Aníbal Castillo}

Antiperonism, Jujuy, Political repression, Representations, Revolución Libertadora Introducción

El gobierno peronista fue depuesto por una coalición opositora en septiembre de 1955; el resultado inmediato del levantamiento fue el establecimiento de un régimen designado por sus promotores como "Revolución Libertadora". Bajo la nueva gestión -que se extendería hasta los primeros meses de 1958-, se puso en operación una serie de procedimientos encauzados hacia la proscripción de los principios organizacionales de la sociedad argentina dejados luego de una década de administración peronista. La desperonización alcanzó a esferas como el ámbito sindical, la escuela y los medios de comunicación, y se diseminó (con mayor o menor énfasis y rapidez) a través del conjunto del territorio.

Tales mecanismos fueron institucionalizados también en la provincia de Jujuy; siguiendo la lógica de las políticas constituidas por el gobierno central, también en esta jurisdicción el peronismo fue objeto de prácticas represivas. Estas estrategias se hicieron ostensibles en la destitución de las autoridades peronistas, la persecución de sus militantes, la prohibición de nombrar a Perón o todo referente al mismo, la depuración de la administración pública y la execración de sus símbolos. Las representaciones invocadas para justificar de manera pública estos procedimientos no pueden plantearse de manera unívoca, dado que depende de los actores colectivos que las invocasen y los contextos específicos dentro de la coyuntura. En este sentido, en cuanto la dinámica del antiperonismo suponía numerosas y profundas disidencias internas, incluso en el espacio acotado de esta provincia, es factible rastrear diversas representaciones sobre el peronismo y en definitiva disímiles posturas sobre qué métodos ejecutar sobre el orden dejado por el mismo.

Más allá de este rasgo particular de la "Libertadora", y omitiendo también la participación de los sectores civiles (como los partidos políticos y las organizaciones vecinales) en el proceso de desperonización, las autoridades provinciales que se sucedieron durante el período construyeron un conjunto categórico de representaciones y principios que habrían de invocar al promover la separación del peronismo de la sociedad jujeña.

El presente artículo apunta en un sentido general, a contribuir a la comprensión de las bases de la violencia estatal en la Argentina a lo largo de la segunda mitad del siglo XX. En términos específicos, el objetivo de este trabajo está orientado a determinar las características de las representaciones que operaron como justificación de la represión política ejecutada contra el peronismo en la provincia de Jujuy durante la Revolución Libertadora.

El artículo fue desarrollado a partir de la consulta de expedientes alojados en los siguientes repositorios: Archivo General de la Nación, Archivo Histórico de la Provincia de Jujuy, Archivo de la Justicia Federal y el Archivo Histórico de Tribunales de la Provincia de Jujuy; asimismo se procedió a la reseña de periódicos resguardados en la Hemeroteca de la Biblioteca Popular de Jujuy. 


\section{La represión antiperonista y su justificación en Jujuy...}

Desde el punto de vista metodológico, se sigue la propuesta de la historia cultural, atendiendo primordialmente a la tesitura de Roger Chartier sobre las representaciones sociales y los aportes de María Estela Spinelli, desde la misma línea, sobre las especificidades del antiperonismo. Finalmente, cabe añadir que el artículo está guiado por la siguiente conjetura: la construcción estatal en esta provincia de las representaciones sobre el peronismo que justificaron su represión habría abrevado en la referencia dominante del antiperonismo radicalizado, aludiendo en particular al presunto carácter totalitario del peronismo.

\section{Consideraciones metodológicas}

La propuesta metodológica de Spinelli parte en líneas generales de que las prácticas de los dirigentes políticos se fundan en la evaluación del escenario en el que se encuentran inmersos: "a partir de su diagnóstico elaboran sus acciones, proyectos y estrategias y lo participan -si son exitosos- a grupos de referencia y opinión [...] que lo adoptan como propio". ${ }^{1}$ Tales definiciones se construyen fundamentalmente en función de lo que Roger Chartier "ha denominado las 'representaciones de la realidad"'.2 Estas últimas están asociadas a "cómo se concibe -desde un ángulo particular de observación a partir de una determinada escala de valores temporal, donde también intervienen ideales, sentimientos y prejuicios- la realidad económica, política, social y cultural de una época". ${ }^{3}$ En definitiva, sostiene Spinelli, los antiperonistas constituyeron representaciones sobre el peronismo y actuaron en función de tales. Cabe agregar que Chartier asevera que los esquemas perceptuales generados por las representaciones contienen "divisiones de la sociedad"; de esta forma las representaciones son productoras de lo social. ${ }^{4} \mathrm{Al}$ respecto, señala que sobre la realidad confluyen múltiples representaciones (dada la complejidad de las formaciones sociales), en función de las cuales esta se construye contradictoriamentea partir de la beligerancia entre distintos grupos que integran la sociedad, que el reconocimiento de las identidades se realiza a partir de prácticas y finalmente, que las representaciones se expresan a partir de mecanismos de institucionalización y objetivación. ${ }^{5}$ Dentro de las sugerencias del autor cabe enfatizar también que las identidades son el resultado de una relación beligerante entre las representaciones "impuestas por aquellos que poseen el poder de clasificar y designar y la definición, sumisa o resistente, que cada comunidad produce de sí misma". ${ }^{6}$

\footnotetext{
1 María Estela Spinelli. Los vencedores vencidos. El antiperonismo y la "Revolución Libertadora". Buenos Aires, Biblos, 2005, p. 14.

${ }^{2}$ Ibídem.

${ }^{3}$ Ibídem.

${ }^{4}$ Roger Chartier. "Prólogo a la edición española", en El mundo como representación. Estudios de historia cultural. Barcelona, Gedisa, 1999, p. IV.

${ }^{5}$ Roger Chartier. "El mundo como representación", El mundo como representación. Estudios de historia cultural. Barcelona, Gedisa, 1999.

${ }^{6}$ Roger Chartier. "El mundo como representación...”, Op. Cit., p. 57.
} 


\section{Fernando Aníbal Castillo}

El estudio de los vínculos entre el peronismo y los discursos, cabe añadir, ha sido abordado por diversos autores. Al respecto, vale mencionar los trabajos de Gerardo Aboy Carlés, ${ }^{7}$ Emilio de Ípola, ${ }^{8}$ Alejandro Groppo, ${ }^{9}$ Ernesto Laclau ${ }^{10}$ y Silvia Sigal y Eliseo Verón. ${ }^{11}$ Nuestra preferencia por la propuesta de Chartier y Spinelli radica tanto en los elementos que privilegian como los que omiten. Al respecto de la teoría del discurso político, debe señalarse que Chartier discute las tesis derivadas del giro lingüístico, desagregadas de la propuesta axiomática de concebir al lenguaje como "un sistema cerrado de signos que producen sentido por el único funcionamiento de sus relaciones".12 Chartier cuestiona que la producción de la significación sea impersonal y automática, desvinculada de la subjetividad, y que la realidad social sea un elemento constituido "por el lenguaje, independientemente de toda referencia objetiva". ${ }^{13}$ Señala que las prácticas constitutivas del mundo social no deben reducirse a la lógica productiva de los discursos. Aun aceptando que la producción discursiva supone la organización del mundo social, no debe equivalerse discurso y realidad social. En otro registro, los trabajos de de Ípola y de Sigal y Verón destacan que la construcción de los discursos se genera a partir de condiciones que son externas a los mismos -las "bases materiales que son su verdadera fuente de inteligibilidad", de acuerdo con de Ípola-. ${ }^{14}$ Consideramos que el problema en torno a las condiciones de los discursos es relevante para la comprensión de la producción de los mismos.

\section{Sobre la represión al peronismo durante la Revolución Libertadora}

Consumada la destitución del peronismo, las fuerzas sublevadas se apropiaron del aparato del Estado. La presidencia de la Nación fue conferida en primera instancia a Eduardo Lonardi, representante de la facción nacionalista del Ejército; su principal lema pregonaba la restitución del imperio del derecho y la pacificación de la

\footnotetext{
7 Gerardo Aboy Carlés. Las dos fronteras de la democracia argentina: la reformulación de las identidades políticas de Alfonsín a Menem. Rosario, Homo Sapiens, 2001.

${ }^{8}$ Emilio de Îpola. 'Desde estos mismos balcones...'. Nota sobre el discurso de Perón del 17 de octubre de 1945", en Juan Carlos Torre, (compilador), El 17 de Octubre de 1945. Buenos Aires, Ariel, 1995 y Emilio de Ípola. "Populismo e ideología (a propósito de Política e ideología en la teoría marxista, de Ernesto Laclau)", en La bemba: acerca del rumor carcelario y otros ensayos. Buenos Aires, Siglo XXI, 2005.

${ }^{9}$ Alejandro Groppo. "Conflicto e identidades en la emergencia del peronismo en la Argentina: entre la territorialidad y la homogeneización". Sociedad Hoy, $\mathrm{N}^{\circ}$ 16. Concepción, 2009, pp. 77-92. Disponible en: http://www.redalyc.org/articulo.oa?id=90217096006 y Alejandro Groppo. "La construcción de la identidad política en los orígenes del peronismo en Argentina y del varguismo en Brasil. Un análisis desde la teoría del discurso político". Papel Político, Vol. XIV, № 1 . Bogotá, 2009, pp. 55-80. Disponible en: <http://www.redalyc.org/articulo.oa?id=77720764004>.

${ }_{10}$ Ernesto Laclau. La razón populista. Buenos Aires, Fondo de Cultura Económica, 2005 y Ernesto Laclau. Politics and ideology in Marxist theory: Capitalism, Fascism, Populism. Londres, New Left Books, 1977.

11 Silvia Sigal y Eliseo Verón. Perón o muerte: los fundamentos discursivos del fenómeno peronista. Buenos Aires, Eudeba, 2004.

${ }^{12}$ Roger Chartier. "Prólogo a la edición...", Op. Cit., p. IX.

13 Ibídem.

${ }^{14}$ Emilio de Ípola. “Populismo e ideología..., Op. Cit., p.96.
} 


\section{La represión antiperonista y su justificación en Jujuy...}

nación. ${ }^{15}$ Spinelli señala que el lonardismo le concedió escasa relevancia a los partidos, sobre todo en la constitución de su gabinete. Esto, sumado a la inacción en contra del peronismo, desacreditó rápidamente la imagen de Lonardi frente al antiperonismo. La conciliación no pudo concretarse, así, por falta de consenso entre las líneas antiperonistas. ${ }^{16}$

La pacificación fue rechazada por el sector más radicalizado del antiperonismo. Sus representantes reclamaban una investigación, juicio y castigo a los responsables de haber colaborado con el ascenso y mantenimiento del peronismo. A los ojos del antiperonismo, la restitución de los valores que Perón les había arrebatado y el reencauzamiento de la política y la sociedad demandaba necesariamente la punición y la proscripción del peronismo. ${ }^{17}$

Cuestionado en definitiva por su displicencia frente a los partidos y por su posicionamiento indulgente con los derrocados, el primer presidente provisional fue desalojado. La línea que cobijaba al primer jefe de Estado "revolucionario" fue segregada en definitiva bajo el argumento de la necesaria depuración ideológica para la reconstrucción democrática de la nación. Este acontecimiento se inscribió en el marco de uno de los procesos centrales que se desenvolvieron entre la revolución de 1955 y la salida electoral de 1958: el desgranamiento paulatino de la coalición antiperonista. La primera depuración de esta alianza le confirió homogeneidad "a los objetivos 'revolucionarios' definidos como democráticos por sus contemporáneos". 18

En lugar de Lonardi, asumió la primera magistratura otro oficial del Ejército, Pedro Aramburu, más proclive a atender la postura liberal y a los partidos políticos. El relevo de la consigna "conciliación" por "democracia”, orientación auspiciada por la tradición liberal-democrática y subsumida bajo la consigna de "Mayo-Caseros", puso de manifiesto el lineamiento que le sería conferida a la Revolución Libertadora. ${ }^{19} \mathrm{La}$ postura del nueve jefe del ejecutivo hacía ostensible así la participación del antiperonismo radicalizado.

Como consecuencia inmediata de la deposición del lonardismo, las prácticas represivas puestas en operación dejaron traslucir que el binomio gubernamental Aramburu-Rojas abandonaría toda ambigüedad. ${ }^{20}$ Los militantes peronistas fueron

\footnotetext{
15 María Estela Spinelli. Los vencedores vencidos..., Op. Cit.

16 María Estela Spinelli. "El debate sobre el orden político durante los primeros gobiernos antiperonistas, 1955-1958”. Anuario del IEHS, № 16. Tandil, 2001, pp. 13-37.

17 María Estela Spinelli. Los vencedores vencidos..., Op. Cit.

18 María Estela Spinelli. “El debate sobre el orden político...”, Op. Cit., p. 19.

19 María Estela Spinelli. “La 'Revolución Libertadora'. Proyección política. Un análisis sobre su lugar en la historiografía”, en María Estela Spinelli; Alicia Servetto; Marcela Ferrari y Gabriela Closa, (compiladoras), La conformación de las identidades políticas en la Argentina del siglo XX. Universidad Nacional de Córdoba, Universidad Nacional del Centro de la Provincia de Buenos Aires, Universidad Nacional de Mar del Plata, Córdoba, 2000.

${ }^{20}$ Julio Melon Pirro. "La corrección de la historia: proyectos institucionales y pedagogía democrática en el primer post-peronismo", en María Estela Spinelli, Alicia Servetto, Marcela Ferrari y Gabriela Closa, (compiladoras), La conformación de las identidades políticas en la Argentina del siglo XX. Córdoba, Universidad Nacional de Córdoba, Universidad Nacional del Centro de la Provincia de Buenos Aires, Universidad Nacional de Mar del Plata, 2000.
} 


\section{Fernando Aníbal Castillo}

apresados e interrogados en función de las prácticas inquisitivas de las comisiones investigadoras, formadas "para atender a las múltiples denuncias de corrupción y abuso de poder que pesaban sobre el gobierno derrocado". ${ }^{21}$ Además, se proscribió el Partido Peronista, se intervino la Confederación General del Trabajo (CGT), la persecución de la militancia peronista adquirió naturaleza sistemática y se sancionó "la penalización de la apelación a sus símbolos".22

En lo que concierne al caso de Jujuy, el Ejecutivo provincial quedó en manos de la Intervención Militar, bajo el comando de un oficial del Ejército. Esta gestión se caracterizó por iniciar la represión al peronismo. No obstante, el discurso del gobierno "revolucionario" provincial favorecía a simple vista la ratificación del programa lonardista, fundado en la conciliación. La representación que construyó la tutela local se manifestó a partir de las palabras de su titular, el mismo día de su asunción; destacando su compromiso con los ideales públicos de la "Libertadora", declaró: "Haré todo lo posible, con la energía necesaria, para que Jujuy [...] se encamine por el camino de paz que le marcan las nuevas autoridades, en procura de la pacificación del país y el reencuentro de sus hijos". ${ }^{23}$ El jefe castrense enfatizó también: "la Intervención Militar no vino a perseguir a nadie"; contrariamente, su misión habría supuesto "unir a todos los jujeños bajo la bandera azul y blanca [...] de acuerdo a los principios espirituales que guían a la Revolución Libertadora". ${ }^{24}$ De esta forma, se preconizaría valores como la paz, la unidad y la libertad de pensamiento y de culto; y este albedrío debería ser el fundamento de una auténtica democracia. Es ostensible que el llamado a la pacificación fue uno de los ejes estructuradores del discurso de esta administración. Lejos de la concordia y la libertad prometidas, sus políticas dieron cuenta rápidamente de sus objetivos.

Los discursos de la Intervención Militar entraron rápidamente en conflicto con las medidas que propiciaba. La primera acción llevada a cabo por la nueva gestión fue la clausura de la Legislatura. Esta disposición fue ejecutada en "concordancia con la medida adoptada por el Superior Gobierno Provisional con el [...] Congreso de la Nación". ${ }^{25}$ En esta misma dirección se procedió luego al cierre de los Concejos Deliberantes de las ciudades del interior. Asimismo, se intervinieron numerosas municipalidades, como la de San Salvador de Jujuy, ahora bajo la égida del Ejército. La celeridad del trámite puso de manifiesto las urgencias y prioridades de la Intervención Militar. La cancelación de las prácticas deliberativas y ejecutivas coadyuvó a la paralización de la "maquinaria" política peronista. Las subsiguientes Intervenciones estuvieron investidas de los mismos rasgos: apuntaban a eliminar al peronismo del espacio público y el campo político.

A partir de la misma emergencia de la Revolución Libertadora se inició la represión y persecución de la militancia peronista, en la que el Ejército tomó activa

\footnotetext{
${ }^{21}$ María Estela Spinelli. “La 'Revolución Libertadora'...”, Op. Cit., p. 191.

22 María Estela Spinelli. “El debate sobre el orden político...”, Op. Cit., p. 19.

${ }^{23}$ Crónica, San Salvador de Jujuy, 24/09/1955.

${ }^{24}$ Jujuy, San Salvador de Jujuy, 27/09/1955.

${ }^{25}$ Archivo Histórico de la Provincia de Jujuy (en adelante AHJ). Boletín Oficial. Segundo semestre. Año 1955. Decreto № 1/G/H.
} 


\section{La represión antiperonista y su justificación en Jujuy...}

participación encarcelándolos. ${ }^{26}$ Asimismo, se dio curso a la depuración de la administración pública; iniciando un proceso que semanas más tarde se exacerbaría, se llevaron a cabo las primeras cesantías. La exoneración del comisionado municipal de Volcán (localidad emplazada en la Quebrada de Humahuaca, a $40 \mathrm{~km}$ al norte de cabecera provincial) fue paradigmático, en cuanto en sus fundamentos se hizo ostensible la posición estatal: "era Secretario de la Unidad Básica que funcionaba en aquel vecindario, lo que importaba actuar en política con evidente olvido de sus deberes de funcionario". ${ }^{27}$

Casi al unísono, la Intervención Militar compelió a retirar "de las oficinas estatales todo símbolo, divisa, afiche, fotografías, efigies y bustos que identifiquen la tendencia política depuesta"; ${ }^{28}$ y demandó el cambio de nombre de las calles que hicieran referencia a los derrocados. ${ }^{29}$ Además, se procedió a retirar textos escolares de los recintos de enseñanza, como Evita, La Argentina de Perón, La razón de mi vida y Patria justa. ${ }^{30}$ El saneamiento de las instituciones estatales fue uno de los basamentos de la Intervención Militar.

Esta primera gestión daría paso rápidamente, en octubre de 1955, a una nueva administración. El escenario que se gestó en Jujuy fue en cierto sentido opuesto a la dinámica nacional. En el caso de esta provincia el alejamiento del interventor se debió a las presiones que el sector yrigoyenista de la Unión Cívica Radical ejerció sobre la gestión militar. Ciertamente, la administración castrense no había prestado mucha atención a los partidos, relegándolos en beneficio de oficiales del Ejército. A la reticencia de la Intervención Militar a incorporar a los partidos a su gestión, debe añadírsele la crudeza de las medidas represivas implementadas. A la inversa de lo acaecido a nivel nacional, en Jujuy, la política coactiva de las autoridades generó rápidamente disconformidad antes que beneplácito, en particular, en el ala yrigoyenista del radicalismo. El recambio de autoridades puso en claro que si bien la dinámica provincial estaba sin dudas sujeta a la lógica de la esfera del gobierno central, la política se desarrollaba también a fuerza de las condiciones locales.

A la primera tutela "libertadora" le siguió la Intervención Federal -cuyo mandato le fue conferido por el Gobierno Nacional al contralmirante Gastón Clement-. Esta desenvolvió también los roles del Ejecutivo provincial intentado consolidar el programa de la "Revolución". Esta gestión, no obstante los reclamos del radicalismo por el escarmiento aplicado a los derrocados, fue sumamente coherente con el planteo del gobierno de Aramburu y Rojas.

Las tendencias fuertemente represivas y antiperonistas en Jujuy fueron prolongadas, ampliadas y organizadas por la segunda intervención. Las políticas de desperonización que se habían desarrollado de manera arbitraria semanas antes

\footnotetext{
26 Archivo Histórico de Tribunales de la Provincia de Jujuy. Conservación Civil 1952-1957. Expediente $\mathrm{N}^{\circ}$ 239/1955 [Expurgo: 1955. Orden: 1].

27 Crónica, San Salvador de Jujuy, 6/10/1955.

28 AHJ. Expediente № 8-I-1955.

${ }^{29}$ AHJ. Expediente № 7-I-1955.

30 Jujuy, San Salvador de Jujuy, 2/10/1955.
} 


\section{Fernando Aníbal Castillo}

fueron investidas ahora de carácter sistemático. La urgencia, que había sido el principio que guió a la Intervención Militar, fue sustituida por un proceso a mediano plazo que se extendió durante los siguientes meses a lo largo de un paulatino desmontaje de los "resabios del totalitarismo". Se profundizaron así todos los mecanismos de expulsión de los peronistas y sus símbolos de las instituciones y de toda la esfera pública, se incrementaron los operativos de represión y asimismo se instauraron procedimientos de indagación que recayeron sobre el "régimen depuesto" y sus acólitos.

Esta gestión abrió paso a una gran cantidad de intervenciones a instituciones de la administración estatal. Fundamentalmente, se inició una campaña de destitución de autoridades en las comunas del interior, como los casos de la Municipalidad de Humahuaca y Comisiones Municipales de Abra Pampa, Estación Perico, Purmamarca, Pampichuela, Santa Catalina, La Esperanza, Maimará, Vinalito, Rinconada, Pampa Blanca y Tumbaya. Por otro lado, a lo largo del proceso de ocupación de las instituciones del Estado, se produjo una sustitución de buena parte de las procuraciones designadas por la primera tutela "revolucionaria". De esta forma, por ejemplo, se cambiaría a los intendentes de origen militar por civiles en la municipalidad de la capital $^{31}$ y en la de Libertador General San Martín (ciudad ubicada en el departamento de Ledesma). ${ }^{32}$

Asimismo, se reforzó el proceso de cesantías. Así, por ejemplo, fueron relevados de sus cargos empleados públicos de La Quiaca, Humahuaca y Tilcara. La lógica inversa se siguió mediante la reincorporación de trabajadores exonerados durante el gobierno peronista, sobre todo en lo que concernía a los docentes. También en el ámbito educativo diversos establecimientos fueron intervenidos, como la Escuela Nacional de Comercio de la ciudad de San Pedro, y el Colegio Nacional y la Escuela Normal, en San Salvador de Jujuy. ${ }^{33}$

Otra de las medidas significativas fue la puesta en operación de dos comisiones investigadoras; una destinada a la indagación en la esfera del Poder Legislativo, y otra con facultades más amplias, que indagó en el ámbito administrativo provincial y en la órbita comunal. Estas instituciones se encargaron de llevar adelante un proceso sistemático de escudriñamiento, y bajo su accionar fueron detenidos numerosos dirigentes del "régimen" destituido; entre estos, fueron arrestados los vicegobernadores Emilio Navea y Juan José Castro.

Por otro lado, se suprimieron instituciones y leyes asociadas al peronismo, como la Subsecretaría de Investigaciones, por su falta de vinculación con el espíritu democrático. También en esta dirección, se procedió a la desocupación de las unidades básicas, como el caso de las de Estación Perico y San Pedro. La Intervención Federal, en una medida de tenor similar, derogó la Ley 2208/1952, por

\footnotetext{
31 Jujuy, San Salvador de Jujuy, 17/11/1955.

32 AHJ. Expediente № 245-I-1955.

33 Fernando Castillo. "Docentes, peronismo y antiperonismo en la provincia de Jujuy (1952-1955)". Revista de la Escuela de Historia, Vol. XI, $\mathrm{N}^{\circ}$ 2. Salta, 2012, s/p. Disponible en: < www.scielo.org.ar/pdf/reh/v11n2/v11n2a03.pdf >.
} 


\section{La represión antiperonista y su justificación en Jujuy...}

la que la Provincia había adherido a la Ley Nacional № 14184 del Segundo Plan Quinquenal. ${ }^{34}$ En este sentido, otras medidas relevantes fueron la disolución del Partido Peronista y de la filial jujeña de la Unión de Estudiantes Secundarios (UES). ${ }^{35}$ Con Clement se inició una embestida contra los trabajadores; así se intervino la CGT y sus gremios, como el Sindicato de Empleados y Obreros Viales de la Provincia, ${ }^{36}$ el Sindicato de Taximetristas de Ledesma y, en San Pedro, la Unión Obrera Argentina, la Unión Obrera de la Construcción, el Sindicato de Obreros Panaderos y el Sindicato de Empleados de Comercio. ${ }^{37}$ Además, se removieron los dirigentes de los sindicatos azucareros y se estableció con dureza la racionalización como principio económico. Este procedimiento se manifestó en la administración pública y también en el marco de las empresas privadas, como los ingenios azucareros.

Finalmente, la Intervención Federal tuvo que comenzar a lidiar con la resistencia peronista, que paulatinamente se fue organizando. Si bien desde los primeros días luego de la expulsión del peronismo sus militantes habían puesto en operación acciones como hacer circular rumores o panfletos, ${ }^{38}$ estos sujetos colectivos irían alcanzando cada vez mayor organización, que se exteriorizaría en la preparación (el primero en Jujuy) de un levantamiento armado. ${ }^{39}$ El gobierno puso en práctica fuertes operativos policiales, en los que se arrestaron a decenas de personas que además del encarcelamiento, eran sometidas a procedimientos judiciales. La represión al peronismo alcanzaría en adelante no solo a aquellos que participaron del "régimen depuesto", sino también de aquellos que pugnaban por reinstalarlo.

El escenario no mutaría con el arribo de una nueva Intervención Federal, a principios de 1956, cuya titularidad fue asignada a Andrés Schack, otro oficial de la Armada. La novel administración continuaría el rumbo instaurado por la anterior. Así, las políticas de desperonización seguirían su curso.

El gobierno mantuvo firme el embate contra el peronismo en dos direcciones: sobre los que fueron sus operadores hasta septiembre de 1955 y contra aquellos que pretendían reinstaurarlo. El gobierno procuró mantener a raya a los gremios, que permanecieron intervenidos. ${ }^{40}$ Uno de los mecanismos mediante el cual la Intervención Federal limitó a los ex funcionarios fue el decreto de inhabilitación "para el desempeño en empleos de la administración pública nacional, provincial y municipal, a las personas que partir del 4 de junio de 1946 se hubieren desempeñado [...] [en cargos directivos] durante el régimen depuesto". ${ }^{41}$ Mediante tal normativa, muchos fueron expulsados de la administración pública y del ámbito educativo por su pasado peronista. Las cesantías, por ejemplo, alcanzaron su punto más álgido durante estos meses, aunque menguarían casi completamente a partir

\footnotetext{
${ }^{34}$ AHJ. Expediente № 126-M-1955

35 Crónica, San Salvador de Jujuy, 20/12/1955.

${ }^{36}$ Libertad, San Salvador de Jujuy, 1/02/1956.

37 Pregón, San Salvador de Jujuy, 24/01/1956.

${ }^{38}$ Archivo de la Justicia Federal. Expediente $N^{\circ}$ 928-1956.

39 Pregón, San Salvador de Jujuy, 24/01/1956.

${ }^{40}$ Libertad, San Salvador de Jujuy, 24/02/1956.

${ }^{41}$ AHJ. Boletín Oficial. Primer semestre. Año 1956. Decreto-Acuerdo № 1143/G/H.
} 


\section{Fernando Aníbal Castillo}

del segundo semestre de 1956. La arremetida contra los ex funcionarios tuvo un cierre con la clausura de la Comisión de Investigación; luego de casi medio año de funcionamiento, con centenares de procedimientos y decenas de detenidos, clausuró sus acciones a fines de marzo de 1956. ${ }^{42}$ Mientras, el peronismo daría pruebas suficientes de su persistencia.

La represión ejecutada sobre los peronistas se llevó a cabo también en junio de 1956. En tal momento, una sublevación de signo opositor al gobierno militar, liderada por Juan José Valle (oficial del Ejército, de orientación nacionalista), favoreció una conmoción sin precedentes. La derrota de las fuerzas insubordinadas en manos de las tropas leales al régimen "libertador" fue seguida del fusilamiento de numerosos insurrectos. No obstante, en Jujuy no se llevaron a cabo ejecuciones, aunque cuantiosos militantes peronistas fueron encarcelados y procesados por su vínculo con la asonada. Aunque durante los meses siguientes la resistencia peronista de esta provincia procuró mantener las expectativas de un triunfo por la vía armada, el peso de represión estatal compelió a los seguidores de Perón a probar por otros caminos, como la lucha partidaria y sindical. ${ }^{43}$

Las autoridades provinciales sostuvieron que la participación local en la intentona de junio de 1956 fue llevada a cabo por "elementos totalmente descentrados y descalificados, del régimen depuesto conjuntamente con unos cuantos descastados que solo han pensado [...] en sus apetitos personales". ${ }^{4}$ Por otro lado, sostenían que las Fuerzas Armadas habían defendido la nación frente a esta embestida, devolviendo la paz espiritual a toda la sociedad argentina; concluían que las prácticas de los actores marciales expresaba "el deseo de defender los conceptos de libertad y democracia, razón de ser de la Revolución Libertadora”. ${ }^{45}$

\section{Acerca de la justificación de la desperonización}

Entre los antiperonistas la representación con mayor consenso, que le otorgaba un sentido global al conjunto de las imágenes sobre el peronismo, "fue la del carácter subversivo del peronismo respecto de los valores políticos y socio-culturales tradicionales". ${ }^{46}$ Desde la llegada de Aramburu a la presidencia, hubo un intento consensuado por establecer a la "democracia" como la idea fuerza del proceso político que advendría. ${ }^{47}$ Esta representación gravitaba en todas las tendencias

\footnotetext{
${ }^{42}$ Archivo General de la Nación. Archivo intermedio. Fondo: Comisión Nacional de Investigaciones. Memorias Comisiones Provinciales: Ch-M. Caja Nº 12 . Expediente $N^{\circ} 22821 / \mathrm{C}$.

43 Fernando Castillo. "El peronismo y la opción partidaria en Jujuy durante la Revolución Libertadora". Trabajos y Comunicaciones, 15. La Plata, 2015, s/p.

${ }^{44}$ Pregón, San Salvador de Jujuy, 12/06/1956.

45 Ibídem.

${ }^{46}$ María Estela Spinelli. "El debate sobre la desperonización. Imágenes del peronismo en los ensayos políticos antiperonistas", en Susana Bianchi y María Estela Spinelli, (compiladoras), Actores, ideas y proyectos políticos en la Argentina Contemporánea. Tandil, Universidad Nacional del Centro de la Provincia de Buenos Aires, Instituto de Estudios Histórico-Sociales, 1997, p. 258.

${ }^{47}$ María Estela Spinelli. "Ideas fuerza en el debate político durante los años de la 'Libertadora', 19551958”. Estudios Sociales, № 24. Santa Fe, 2003, pp. 61-88.
} 


\section{La represión antiperonista y su justificación en Jujuy...}

ideológicas y fue uno de los fundamentos del acuerdo básico a partir del cual los diversos sectores políticos coincidieron en la necesidad de la desperonización. Los parámetros que guiaron el debate en torno a cómo redefinir el orden político se fundaron en los significados de los acontecimientos que estaban protagonizando y en "la caracterización de la aborrecida experiencia de diez años de gobierno peronista" ${ }^{48}$ El conjunto del antiperonismo coincidía en "un sentimiento y un objetivo político compartido, poner fin a un estado de cosas para ellos intolerable que era el peronismo y fundamentalmente a Perón como presidente". 49

El antiperonismo radicalizado representaba al peronismo como una copia del fascismo y aborreció su condición vulgar, expresada en sus dirigentes y en el uso del lenguaje de los sectores populares. Estos actores, frente al peronismo, proponían la desfascistización y la desnazificación. ${ }^{50}$ Además asumían la democracia como una ética política, orientada fundamentalmente a "garantizar los principios liberales consagrados por la Constitución de 1853" y, asimismo, asegurar la representación de las minorías. ${ }^{51}$ Por otro lado, aspiraban a "refundar el orden republicanodemocrático"; para lo cual era imprescindible la supresión del peronismo. ${ }^{52}$

El trazado de los basamentos operativos de la desperonización invocados en esta provincia no distó de aquellos propuestos por el gobierno central, de fuerte talante radicalizado. Sin embargo, aunque la represión sobre los elementos y militantes de cuño peronista supuso una política connivente con los postulados nacionales que privilegiara su erradicación, la aplicación de tales medidas en este distrito tuvo la atención puesta sobre la depuración de las instituciones estatales. ${ }^{53}$ Esta cuestión, no obstante, no debe escamotear el hecho de que los fundamentos de las prácticas desperonizadoras estaban conferidos de una perspectiva integral, destinada a impactar sobre la totalidad de las esferas.

En una primera instancia, la Intervención Militar declaró que el trasfondo de sus acciones de gobierno suponía la pacificación; las mediaciones estatales habrían comportado así como objetivo el cese de las hostilidades sociales y políticas entre los actores en pugna. Esta primera gestión, al margen del escaso tiempo que duró, adoptó una postura bastante reticente a especificar sobre qué otros cimientos se apoyaban sus determinaciones (más allá de reproducir taxativamente la prédica lonardista). Sin embargo, el titular de la Intervención Militar no se privó de pronunciarse al respecto. Por ejemplo, en relación a la medida de remover los nombres de los lugares públicos alusivos al peronismo, adujo que se la promulgaba

\footnotetext{
48 María Estela Spinelli. “El debate sobre el orden político...”, Op. Cit., p. 25.

49 Ibídem.

${ }^{50}$ María Estela Spinelli. “La construcción del Frente Nacional en la Argentina post-peronista, 19551958. ¿Una estrategia electoral o un proyecto político modernizador?". Estudios Interdisciplinarios de América Latina y el Caribe, Vol. III, № 1 . Tel Aviv, 1992, pp. 93-108.

${ }^{51}$ María Estela Spinelli. “La construcción del Frente Nacional...”, Op. Cit. pp. 96-97.

52 María Estela Spinelli. “El debate sobre la desperonización...”, Op. Cit., p. 240.

${ }^{53}$ Debe considerarse que en la provincia de Jujuy, más allá el rol que de por sí ganó el Estado a través de medidas intervencionistas durante los años peronistas, el peso del gobierno en el empleo era sumamente considerable, sobre todo en los valles centrales y particularmente, en la ciudad capital.
} 


\section{Fernando Aníbal Castillo}

"Atento a la hora de recuperación integral que vive el país en los actuales momentos". 54 No obstante, menos ambiguos fueron los considerandos bajo los cuales se procedió a intervenir la Municipalidad de Tilcara: tal medida se proclamó a propósito de brindar mejores servicios y por ética administrativa. ${ }^{55}$ Aunque en el texto de la disposición no se explicitó qué era la "ética administrativa", el decreto se refería indudablemente al saneamiento moral que en adelante las intervenciones realizarían sobre las reparticiones públicas. La alusión al mejoramiento de los servicios brindados por los organismos del Estado tuvo fuerte preponderancia en los discursos de las intervenciones, fundamentalmente en el marco de los procedimientos de desalojo de los funcionarios emparentados con el "régimen depuesto". Los dirigentes "revolucionarios" concebían que el problema del Estado peronista radicaba en parte en su inherente ineficacia, propia, por supuesto, de la incapacidad técnica y moral de sus gestores. Como se verá, este principio sería recurrentemente invocado.

Por otro lado, otro objetivo de la gestión conllevaba la recuperación y consolidación de "las libertades y los derechos conculcados asegurando al pueblo el libre ejercicio de todos los derechos democráticos, en busca de la plena vigencia de la Constitución". ${ }^{56}$ La ya mencionada proscripción de textos escolares también estaba investida de fundamentos categóricos: los niños no debían quedar subsumidos bajo la propaganda ni la política. ${ }^{57}$

De esta forma, se puede inferir que las plataformas representacionales con mayor gravitación, que serían recogidas con fuerte énfasis durante los siguientes meses, entrañaban lo siguiente: la compostura de la administración pública (tanto ética como técnica), la restitución de la libertad, la erradicación de la propaganda, el restablecimiento de los derechos, la prescindencia de la política y la salvaguarda de la niñez. En un sentido general, los elementos propuestos pueden ser rastreados sin dudas en las acusaciones que pesaron sobre el peronismo durante la década pasada. Lo que esta primera administración "revolucionaria" inauguró fue el posicionamiento de estos postulados como política de Estado.

La llegada de la primera Intervención Federal dio un paso más allá en relación a los principios que debería seguir la expresión provincial de la Revolución Libertadora. A diferencia de su antecesora, esta nueva gestión participó activamente en el espacio público, haciendo ostensibles sus postulados. Estos últimos se explicitaron además rotundamente en los textos oficiales, sobre todo en la promulgación de los decretos. En este contexto, debe considerarse de qué forma las dinámicas oficiales construyeron las representaciones sobre el peronismo (más allá de las tácitas alusiones a la política del Superior Gobierno Provisional, que confirieron tonalidad al imaginario provincial). Las enunciaciones de las autoridades locales operaron mediante un mecanismo de diferenciación, a través del cual la representación sobre

\footnotetext{
${ }^{54}$ AHJ. Expediente № 7-I-1955.

55 AHJ. Expediente Sin número-I-1955.

${ }^{56}$ Jujuy, San Salvador de Jujuy, 4/10/1955.

57 Jujuy, San Salvador de Jujuy, 2/10/1955.
} 


\section{La represión antiperonista y su justificación en Jujuy...}

el peronismo suponía el opuesto pleno de la Revolución Libertadora. En los ejemplos que se mencionan a continuación, se evidencia la reconstitución del campo políticocultural; en rigor, las representaciones aludidas anclaron en un espacio polarizado precedente (construido en función de la contienda entre peronistas y antiperonistas durante el decenio anterior), aunque a la luz del nuevo contexto político, que demandaba resignificaciones específicas.

En su discurso de asunción, el contraalmirante Clement tornó patente el carácter fundacional de la "Libertadora" y asimismo la dicotomía irreconciliable entre ambos gobiernos: "Comienza otra jornada que conducirá indefectiblemente a la victoria total del pueblo de mi patria sobre los malos argentinos que intentaron torcer la voluntad de constituir siempre un pueblo libre y bueno". 58

La separación de las características de uno y otro sistema político se desempeñó por medio de un cedazo clasificatorio, que dotaba necesaria e insistentemente a la "Revolución" de propiedades inherentes a los gobiernos democráticos, federalistas y morales; al peronismo no solo le privaba este carácter, sino que le confería inflexiblemente las peculiaridades propias de las gestiones totalitarias. Las concepciones acerca de la naturaleza del gobierno derrocado se evidencian en el párrafo que sigue:

[El peronismo] no condice con el espíritu democrático [...] pues son resabios del sistema totalitario que imperó hasta el 16 de septiembre, ya que tenían como finalidad la anulación de la libertad y la implantación de un régimen de temor dentro de la población, que se utilizaba para cercenar los derechos de la personalidad civil y política, disponer arbitrariamente de la honra y el honor de los ciudadanos, manejar incontroladamente los dineros del pueblo y propagar conceptos y sentimientos que deformaban la raigambre histórica de la Nación y la conciencia de los hombres. ${ }^{59}$

La Intervención suponía que el peronismo se oponía a valores que consideraba fundamentales; y que había conculcado los "principios de la moral, de la paz, de la ley y de la libertad". ${ }^{60}$ El fin último del peronismo habría sido el establecimiento de un régimen totalitario que "solo reconocía la obsecuencia y el servilismo". ${ }^{61}$

La construcción del peronismo como objetivación vernácula del autoritarismo fue reproducida luego del recambio de autoridades provinciales. Para la administración siguiente, el gobierno peronista conllevó "la más espantosa tiranía, que constituyó durante 12 interminables años, la noche más fría y tenebrosa de nuestra historia". ${ }^{62}$ Los discursos de esta gestión también tuvieron para el peronismo solo consideraciones lúgubres:

Durante la tiranía no ha existido ni siquiera un vestigio de libertad. Todos los argentinos estábamos obligados a pensar o sentir como el déspota. [...] Tampoco

\footnotetext{
58 Jujuy, San Salvador de Jujuy, 8/10/1955.

${ }^{59}$ AHJ. Boletín Oficial. Segundo semestre. Año 1955. Decreto Ley № 10/G/H.

60 Jujuy., San Salvador de Jujuy, 23/11/1955.

61 Ibídem.

62 Libertad, San Salvador de Jujuy, 16/03/1956.
} 


\section{Fernando Aníbal Castillo}

hubo democracia en el tiempo de la tiranía [...] ¿Cómo puede haber democracia cuando se pusieron todos los órganos de publicidad oficiales y particulares al exclusivo servicio del partido de la dictadura y fueron perseguidos todos aquellos que no se prestaron a ensalzar los caprichos del tirano? ${ }^{63}$

Nuevamente, se evidencia el rechazo a la presunta condición dictatorial del peronismo y la preconización de la democracia, el republicanismo y el federalismo, repetidos incansablemente. La libertad, la justicia, la verdad y el honor. El amor a la patria. En alocuciones posteriores se ensalzaría la niñez y la juventud, la familia y la escuela, y los auténticos héroes y símbolos nacionales. ${ }^{64}$ Hubo una recurrencia a la "Patria" como referente organizador de la experiencia y como elemento identitario estructurador del conjunto de las identidades tradicionales o (re) emergentes. Este planteo se manifestó en alocuciones como la que sigue: "Solamente unidos en un ideal común de Patria será posible retomar las normas democráticas y restaurar los principios morales y condiciones económicas que el país necesita para reanudar su marcha". 65 La subsunción de los intereses sectoriales al bien común de la Patria fomentaría así la superación del estado de crisis dejado por el peronismo.

Por otro lado, se manifestaron otras referencias fundamentales, que identificaban al programa del peronismo como el montaje de una farsa; 66 tal postura -que se evidenció, como las restantes, a través de la prensa- denunciaba la inexistencia de una política de industrialización ${ }^{67}$ y que la riqueza no había sido invertida en obras, sino, desfalcada: las únicas obras del gobierno peronista, como adujeron las autoridades de la "Libertadora", habrían sido "edificios hechos a los costados de los caminos para que los pasantes pudieran leer los correspondientes carteles de propaganda".68

La administración de los bienes del erario público también fue objeto de controversia; el aumento de la deuda estatal durante la década pasada contrastaba con el temple racionalizador de la Intervención Federal. ${ }^{69}$ En definitiva, subyacía en torno a estos un tinte no solo de condena al gobierno depuesto, sino también de proclama justificadora, dirigida a legitimar las prácticas de desperonización. La

\footnotetext{
63 Ibídem.

${ }^{64}$ AHJ. Boletín Oficial. Segundo semestre. Año 1955. Decreto № 245/G.

${ }^{65}$ Libertad, San Salvador de Jujuy, 20/12/1955.

66 Spinelli sostiene que esta política, de carácter pedagógico, suponía la mostración de las "aberraciones" morales y políticas del gobierno peronista, desmitificándolo y "mostrando lo que a su entender había sido su 'verdadero' significado". Al respecto, la autora señala: "El resultado de la actividad de la investigación al que la prensa comercial dio amplia cobertura, constituyó una parte esencial del proyecto pedagógico de la desperonización. Éste tenía por finalidad, además del castigo a los culpables, convencer a los peronistas de que habían sido víctimas de un 'engaño', por eso se manifestó en los primeros momentos a través de la exhibición del lujo del gobierno anterior". María Estela Spinelli. Los vencedores vencidos..., Op. Cit. pp. 66-67.

${ }^{67}$ Se acusaba, asimismo. al gobierno derrocado de la liquidación de los vínculos comerciales y la cancelación de la Argentina agroexportadora. El problema de la intervención del Estado en la economía sería retomada de alguna forma posteriormente; a través de un balance de su gestión, el interventor Clement sostuvo que se había restituido a la provincia el devenir normal de la "libre empresa". Libertad, San Salvador de Jujuy, 21/02/1956.

${ }^{68}$ Libertad, San Salvador de Jujuy, 6/12/1955.

${ }^{69}$ Libertad, San Salvador de Jujuy, 27/12/1955.
} 


\section{La represión antiperonista y su justificación en Jujuy...}

conformación del peronismo como anomalía (enfatizando su naturaleza impugnadora y devastadora) favorecería el reconocimiento de la institución de contrapesos que reequilibrasen la condición sombría del estado dejado por Perón y sus huestes.

El proceso oficial de desafección discursiva que recayó sobre el peronismo iría menguando paulatinamente, no tanto porque el mismo hubiese sido efectivamente anulado, sino porque en la execración del mismo ganó mayor preponderancia la prensa. Por otro lado, la reactivación de los partidos también restó protagonismo a las Intervenciones. Cabe insistir en que no se pretende menoscabar el papel que el Estado asumió en la constitución del imaginario antiperonista y en la formulación de los fundamentos de la desperonización, sino que se produjeron desplazamientos. En este sentido, puede decirse que la execración del peronismo por parte de los "revolucionarios" provinciales tuvo su ápice en el triunfo militar de junio de 1956 y un cierre a principios de 1957; durante la administración de Vitón, la prédica "libertadora" tuvo en adelante otro matiz, signado por la amenaza del radicalismo. Sin embargo, cabe acotar que el trato que el último interventor dispensó al peronismo no distó de manera alguna del de sus predecesores.

\section{Conclusiones}

La provincia de Jujuy constituyó un espacio de intervención del antiperonismo encarnado en el Estado. Las prácticas coactivas (en sus diversas expresiones) siguieron la lógica centralizada bajo el gobierno nacional e impactaron en diversas medidas sobre el peronismo, erradicándolo del espacio público, eliminándolo de las instituciones estatales y proscribiéndolo en definitiva. En este sentido, la dinámica provincial (más allá de algunos matices en lo que concierne al devenir político local) supuso la ratificación del programa de desperonización trazado (con mayor o menor sistematicidad) antes que la introducción de desvíos en la política oficial.

Lo planteado con respecto a los principios de la desperonización permite establecer que las características que asumieron las Intervenciones eran propias del antiperonismo radicalizado. Las representaciones que formularon sobre el peronismo lo identificaban necesariamente como una dictadura, de carácter aberrante. La apelación a ciertos conceptos y símbolos implicó la reproducción de las tendencias traídas, nuevamente, de las prescripciones trazadas por el gobierno central. El conjunto de los preceptos bajo los cuales se construyó la representación del peronismo recuperó de manera evidente la tradición liberal.

Los fundamentos de la desperonización y la represión política no escamoteaban la tensión y la naturaleza que en definitiva era característica de la Revolución Libertadora: la libertad implicaba un objetivo que demandaba la exclusión de un sector mayoritaria de la sociedad. Este régimen instauró un mecanismo constituyente de la vida política de esta provincia (en el contexto general de esta nación, sin dudas), que se basaba en la formulación (más o menos sofisticada y 


\section{Fernando Aníbal Castillo}

sistemática) de principios de justificación de la represión política con la mira puesta en la libertad.

\section{Bibliografía}

Gerardo Aboy Carlés. Las dos fronteras de la democracia argentina: la reformulación de las identidades políticas de Alfonsín a Menem. Rosario, Homo Sapiens, 2001.

Fernando Castillo. "Docentes, peronismo y antiperonismo en la provincia de Jujuy (1952-1955)". Revista de la Escuela de Historia, Vol. XI, № 2. Salta, 2012, s/p. Disponible en: < www.scielo.org.ar/pdf/reh/v11n2/v11n2a03.pdf >.

Fernando Castillo. Antiperonismo y resistencia en Jujuy durante la Revolución Libertadora. Tesis de Doctorado. San Miguel de Tucumán, Universidad Nacional de Tucumán, 2014.

Fernando Castillo. "El peronismo y la opción partidaria en Jujuy durante la Revolución Libertadora”. Trabajos y Comunicaciones, 15. La Plata, 2015, s/p.

Roger Chartier. "Prólogo a la edición española", en El mundo como representación. Estudios de historia cultural. Barcelona, Gedisa, 1999.

Roger Chartier. "El mundo como representación", El mundo como representación. Estudios de historia cultural. Barcelona, Gedisa, 1999.

Emilio de Ípola. “'Desde estos mismos balcones...'. Nota sobre el discurso de Perón del 17 de octubre de 1945", en Juan Carlos Torre, (compilador), El 17 de Octubre de 1945. Buenos Aires, Ariel, 1995.

Emilio de Ípola. "Populismo e ideología (a propósito de Política e ideología en la teoría marxista, de Ernesto Laclau)", en La bemba: acerca del rumor carcelario y otros ensayos. Buenos Aires, Siglo XXI, 2005.

María Silvia Fleitas y Adriana Kindgard. "Entre la legalidad y la proscripción. Políticas públicas y lucha obrera en Jujuy", en Ana Teruel y Marcelo Lagos, (directores), Jujuy en la historia. De la colonia al siglo XX. San Salvador de Jujuy, Ediunju, 2006.

Alejandro Groppo. "Conflicto e identidades en la emergencia del peronismo en la Argentina: entre la territorialidad y la homogeneización”. Sociedad Hoy, № 16.

Concepción, 2009, pp. 77-92. Disponible en: <http://www.redalyc.org/articulo.oa?id=90217096006>.

Alejandro Groppo. "La construcción de la identidad política en los orígenes del peronismo en Argentina y del varguismo en Brasil. Un análisis desde la teoría del discurso político". Papel Político, Vol. XIV, N 1 . Bogotá, 2009, pp. 55-80. Disponible en: <http://www.redalyc.org/articulo.oa?id=77720764004>.

Adriana Kindgard. Alianzas y enfrentamientos en los orígenes del peronismo jujeño. San Salvador de Jujuy, Unidad de Investigación en Historia Regional, FHYCS, UNJU, 2001.

Adriana Kindgard. "Ruptura partidaria, continuidad política. Los 'tempranos' orígenes del peronismo jujeño", en Darío Macor y César Tcach, (editores), La 


\section{La represión antiperonista y su justificación en Jujuy...}

invención del peronismo en el interior del país. Santa Fe, Universidad Nacional del Litoral, 2003.

Ernesto Laclau. Politics and ideology in Marxist theory: Capitalism, Fascism, Populism. Londres, New Left Books, 1977.

Ernesto Laclau. La razón populista. Buenos Aires, Fondo de Cultura Económica, 2005.

Julio Melon Pirro. "La corrección de la historia: proyectos institucionales y pedagogía democrática en el primer post-peronismo”, en María Estela Spinelli, Alicia Servetto, Marcela Ferrari y Gabriela Closa, (compiladoras), La conformación de las identidades políticas en la Argentina del siglo XX. Córdoba, Universidad Nacional de Córdoba, Universidad Nacional del Centro de la Provincia de Buenos Aires, Universidad Nacional de Mar del Plata, 2000.

Julio Melon Pirro. El peronismo después del peronismo: resistencia, sindicalismo y política luego del 55. Buenos Aires, Siglo Veintiuno, 2009.

María Estela Spinelli. Los vencedores vencidos. El antiperonismo y la "Revolución Libertadora”. Buenos Aires, Biblos, 2005.

Silvia Sigal y Eliseo Verón. Perón o muerte: los fundamentos discursivos del fenómeno peronista. Buenos Aires, Eudeba, 2004.

María Estela Spinelli. "La construcción del Frente Nacional en la Argentina postperonista, 1955-1958. ¿Una estrategia electoral o un proyecto político modernizador?". Estudios Interdisciplinarios de América Latina y el Caribe, Vol. III, $\mathrm{N}^{\circ}$ 1. Tel Aviv, 1992, pp. 93-108.

María Estela Spinelli. "El debate sobre la desperonización. Imágenes del peronismo en los ensayos políticos antiperonistas”, en Susana Bianchi y María Estela Spinelli, (compiladoras), Actores, ideas y proyectos políticos en la Argentina Contemporánea. Tandil, Universidad Nacional del Centro de la Provincia de Buenos Aires, Instituto de Estudios Histórico-Sociales, 1997.

María Estela Spinelli. “La 'Revolución Libertadora'. Proyección política. Un análisis sobre su lugar en la historiografía”, en María Estela Spinelli; Alicia Servetto; Marcela Ferrari y Gabriela Closa, (compiladoras), La conformación de las identidades políticas en la Argentina del siglo XX. Universidad Nacional de Córdoba, Universidad Nacional del Centro de la Provincia de Buenos Aires, Universidad Nacional de Mar del Plata, Córdoba, 2000.

María Estela Spinelli. "El debate sobre el orden político durante los primeros gobiernos antiperonistas, 1955-1958". Anuario del IEHS, № 16. Tandil, 2001, pp. 1337.

María Estela Spinelli. "Ideas fuerza en el debate político durante los años de la 'Libertadora', 1955-1958”. Estudios Sociales, N²4. Santa Fe, 2003, pp. 61-88.

Recibido: 22/02/2016

Evaluado: 25/03/2016

Versión Final: 14/04/2016 